\title{
The Early Zhou Period: Origin of the Idea of Political Legitimacy and the Political Philosophy of Confucianism
}

\author{
DU Lun*
}

\begin{abstract}
The Chunqiu and Zhanguo Periods are usually regarded as the birth of Chinese philosophy, especially with regard to practical or moral philosophy. If we think about the concept of political legitimacy in the Early Zhou Period, with ideas like the "Mandate of Heaven", "respect virtue" and "protect ruled people", then this Period is not only the origin of this in ancient China, but also of Chinese philosophy, and primarily the political philosophy of Confucianism.

The paper will first explain some documents in the "inscriptions on ancient bronze objects" in order to prove that the ideas of the "Mandate of Heaven", "respect virtue" and "protect ruled people" really originated from this time. Through analysis of several Zhou documents from the Book of the Documents the paper will then demonstrate that these ideas are the three most important innovations in the history of Chinese thinking at that time.
\end{abstract}

Keywords: Early Zhou Period, idea of political legitimacy, "Mandate of Heaven”, "respect virtue", "protect ruled people"

\section{Zgodnje obdobje Zhou: izvor ideje o politični legitimnosti in politični filozo- fiji konfucionizma}

\section{Izvleček}

Obdobji Chunqiu in Zhanguo sta običajno predstavljeni kot začetek kitajske filozofije, zlasti z ozirom na praktično ali moralno filozofijo. Ce obravnavamo koncept politične legitimnosti v zgodnjem obdobju Zhou, z idejami, kot so »nebeški mandat«, »vrlina spoštovanja« in »ljudstvo pod zaščitniškim vodstvom«, to obdobje ne predstavlja le njihovih začetkov v stari Kitajski, temveč tudi izvor kitajske filozofije in predvsem politične filozofije konfucionizma.

Prispevek najprej obrazloži nekatere dokumente, ohranjene $\mathrm{v}$ »Zapisih na starodavnih bronastih predmetih«, s čimer poskuša dokazati, da ideje o »nebeškem mandatu«, »vrlini

DU Lun, PhD., Senior lecturer in Chinese, University of Duisburg-Essen, Germany.

lun.du[at]uni-due.de

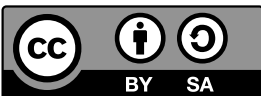


spoštovanja« in »ljudstvu pod zaščitniškim vodstvom« izvirajo iz tega obdobja. $Z$ analizo več dokumentov iz obdobja Zhou, ohranjenih v Knjigi dokumentor, prispevek nato prikaže, da so te ideje tri najpomembenjše inovacije v zgodovini kitajske misli tega obdobja.

Ključne besede: zgodnje obdobje Zhou, ideja politične legitimnosti, »nebeški mandat«, "vrlina spoštovanja« in »ljudstvo pod zaščitniškim vodstvom»

\section{Introduction}

The Chunqiu and Zhanguo Periods are usually regarded as the birth of Chinese philosophy, and especially of practical or moral philosophy. If we think about the ideas of political legitimacy in the Early Zhou Period, such as the "Mandate of Heaven” (tianming 天命), “respect virtue” (jing de 敬德) and “protect ruled people” (bao min 保民), and remember that the Shang Dynasty and those before this had not produced any documents concerning these concepts, so the Early Zhou Period should be considered as origin of Chinese philosophy, and primarily the political philosophy of Confucianism. This idea of political legitimacy in the Early Zhou Period includes not only political and ethical elements, but also religious ones. At the same time the rulers of the Zhou Period established based on the so-called “patriarchal clan system" (zongfazhi 宗法制) the Chinese feudal system which is different from the one that existed in medieval Europe.

If we compare these political practices and the thoughts of the ruling class of the Zhou with regard to "how to govern", and recall how ancient Greece established several different political forms and constitutions at the same time, with the focus being on "how to construct a state (polity)", then it is easy to see that the idea of political legitimacy, and the understanding of both politics and political philosophy in ancient China, were different from those in Europe.

In this paper I would first like to explain some documents in the "inscriptions on ancient bronze objects" (jin wen 金文) in order to prove that the theories of the "Mandate of Heaven", "respect virtue" and "protect the ruled people" really originated from this time. Then I will analyse several Zhou documents from the Book of the Documents (Shujing 书经) in order to demonstrate that these theories were the three most important innovations in Chinese political thinking at that time.

\section{The Documents in the "Inscriptions on Ancient Bronze Objects" (金文)}

The three pillars of political legitimacy in ancient China, namely the "Mandate of Heaven", "respect virtue" and "protect ruled people" were actually developed in the 
Early Zhou Period. This can be proved by examining the documents in the "inscriptions on ancient bronze objects", such as the document known as the $\mathrm{Da} Y \mathrm{Yu}$ Ding (大孟鼎). This is a “certificate of appointment" (ce ming shu 册命书) of the third King Kang (康王) to the officer Yu (孟). In this document the King gives a territory and its population to an officer, who will then be its ruler. This act can be understood as fengjian (封建), which is translated as “feudal".

Let us at first view the following passage in the Da Yu Ding: 丕显文王, 受 天佑大命。在武王, 嗣文作邦。[...... 敷有四方, 畯正厥民. (Wang 2006, 65-66) As we can see, the King said to Yu, King Wen received the Mandate of Heaven to help him (Heaven) to rule and King Wu (son of King Wen) carried on with this mandate and established the state of Zhou.

In another passage of this document we learn that King Wen has received through the Mandate of Heaven “people and their territories”: 粤我其通省先王受民受疆 土. (ibid., 66). The word shou (受 which we translate as "receive") Debson (1962, 221-5) interpreted as "take under the my governance", i.e. "the government of the King of Zhou". Of course, we can say that the kings of Zhou naturally think that it is legitimate for them to rule the territory they have conquered.

Besides the word tian 天 (Heaven) we can also find the word de 德 (virtue) in the Da Yu Ding, for example in the phrase 敬雍德經. Debson (ibid., 225) translated this as "reverently to bring all in consonance with the canon of virtue". The word de 德 occurs in several other documents in the "inscriptions on ancient bronze objects", such as in the He Zun (He 尊) from the time of the second King Cheng (成王): 唯王恭德裕天. We can translate this as "King Wen respects virtue and makes sacrifices to Heaven". Even the expression jing de (敬德) is found, for example in the document of the ritual container Ban Gui (班篮) from the time of the fifth King Mu (穆王): 彝昧天命, 故亡, 允哉顯, 唯敬德. (Wang 2006, 100-1) This last sentence means "(Therefore) the people should respect virtue".

Let us turn again to the last sentence in the above quoted passage: 畯正厥民. Debson $(1962,221-5)$ translates this word 正, which we usually give the meaning "correct" today, as "govern". What is the reason for this? In classical Chinese we can find three words which are pronounced like zheng (in different tones, of course) and concern politics: 正, 征 and 政. (Ma and Xiao 1991, 1009-14) The first word 正 originally means "correct" in ancient China. ${ }^{1}$ And the second word 征 usually means "go on a journey", and therefore also "go on an expedition", as in the "inscriptions on bones or tortoise shells of the Shang Dynasty". (Ma 2014, 4). Words with this meaning are also sometimes written as 正 (correct). (ibid., 24)

1 For example 仪正而景正 (If the sundial stands straight, then the shadow is correct) in 荀子・君 道 (Xunzi Book 12, Way of the Sovereign). 
Finally, the word 政 usually has something to do with politics. But both in the "inscriptions on bones or tortoise shells of the Shang Dynasty" and "inscriptions on ancient bronze objects" we can find this word being used with the meaning "go on an expedition" (ibid., 80), The fact is that these three words have similar meanings and are therefore connected with each other. For example, "to go on an expedition" is generally used in relation to punishing the people because of their mistakes and so aiming to correct their behaviour. Moreover, for the ruling class of the Zhou Dynasty the most important task of a ruler is just to educate the people.

As such, the core meaning of these three words is "to correct". Let us thus analyse the sentence 畯正厥民 in more detail. Because the object of the verb 正 (to correct) in 畯正厥民 is 厥民 which should be translated as "his or their people", so we can say that the Kings of Zhou regarded the people in their new territories as their own people. It is thus difficult to interpret it as meaning "go on an expedition" rather than "govern". If this interpretation is correct, it would be in correspondence with the general understanding of politics at that time: "To govern" means "the ruler should be correct" and thus "to correct the behaviour of the ruled people". We think here about the famous saying of Confucius: 政者, 正也 ${ }^{3}$ (to govern just means to correct).

Moreover, it is also interesting to consider the meaning of the word 畯 before 正. Besides the Da Yu Ding the word 畯 is also found in other documents of the "inscriptions on ancient bronze objects" and is regarded by some scholars as a synonym of 俊 (jun) and 悛 (quan). Because the last word means "change" (改), (HYDCD 1986, 4: 2307), so we can interpret the word 畯 as meaning "to bring ruled people to correct their mistakes and to become good people” (使民改过向 善). (Wang 2006, 148)

As I will show later, the "education of ruled people" is part of the idea of "to protect ruled people". In the "inscriptions on ancient bronze objects" of the Early Zhou we can find evidence for all these ideas, namely those of the "Mandate of Heaven", "respect virtue" and "protect ruled people".

\section{The Zhou Documents from the Shujing (书经)}

The American scholar Michael $(1986,27)$ regards the Zhou Era as "the age of reason", so we can consider the "Mandate of Heaven", "respect virtue" and "protect

2 For example in 毛公鼎 (Mao gong ding) (Wang 2006, 263).

3 论语·颜渊 (Lunyu 12.17) and 孔子家语 - 大婚解第四 (Kongzi Jiayu (Expressions from the Home of (onfucius), Dabunjie 4). 
ruled people", three theories of the Zhou rulers, as the three most important innovations in the history of Chinese political thinking at that time.

With the battle in Muye (牧野) the Zhou defeated the Shang and established a new kingdom in China. Their new dynasty needed legitimacy, not only for the ruled people, but also for the former rulers, namely the aristocrats and the former officers of the Shang Dynasty, as well also for themselves. The new rulers have to be self-confident about the rightness of their assumption of power. The first part of their idea of political legitimacy is the theory of the "Mandate of Heaven".

The new ruling class thus tried to propagate this idea. They argued that their revolt against the Shang was not because of their own desires, but instead because of the wishes of Heaven (天). As an example we can first quote some passages in the chapter “Kanggao" (康诰), ${ }^{4}$ an imperial mandate from Duke Zhou (周公) to his younger brother Kang. He writes, "(Our) dead father King Wen was able to make bright virtue and to be careful about punishment" 5 and it "was heard by High Lord and (High) Lord favoured him. Heaven then grandly ordered King Wen to kill the great Yin and grandly receive its mandate, its states and people."6 Duke Zhou (in the chapter Duoshi (多士)) explained to the remaining Shang officers of why the previous rulers had lost the "Mandate of Heaven" to the Zhou, as follows: "How should we have dared to seek the throne? The (High) Lord did not give favour (to Yin); what our lower people held on to and did was (the expression of) Heaven's discernment and severity."

The first part of the "Mandate of Heaven" is the so-called "receiving of the Mandate of Heaven" (受天命). In order to understand this innovation we have to explain the term tian (Heaven). The highest deity of the Shang was the High Lord (上帝), and the Shang believed that the he only protected the people of Shang, and so they did not need to do anything special in order to have his protection.

4 The chapter Kanggao (康诰) builds a unity with the chapters Jiugao (酒诰) and Zicai (梓材). It is debatable as to whether Duke Zhou (周公) or King Wu (武王) is the author of these three chapters, although traditionally Duke Zhou was seen as such. Sima Qian (司马迁: ca. 145-90 BCE, author of the "Documents of History" (史记)) for example has this opinion. (See 史记・周本纪第 四) But in the Song Era (960-1279) this opinion was revised. (See Jiang 1988, 237-47) Now most Chinese scholars see Duke Zhou as the author. (See You 2001, 182; Zhang 2005, 27-28 and Zang 1999, 307-8)

5 惟乃丕显考文王, 克明德慎罚.

6 惟时怙冒, 闻于上帝, 帝休, 天乃大命文王。殪戎殷, 诞受厥命越厥邦民, 惟时叙, 乃寡 兄劰。

King Wu used the word shangdi (上帝, hear: translated as High Lord), but surely meant tian 天 (Heaven): although the Zhou have the highest deity of 天 (Heaven), they sometimes used the term shangdi (上帝) or di (帝: Lord), when they spoke about tian 天 (Heaven).

7 我其敢求位? 惟帝不界, 惟我下民秉为, 惟天明畏。 
After their victory over the Shang, the Zhou needed to establish a new highest deity, and this was Heaven. The Zhou tried to convince themselves and the remaining Shang officers that Heaven does not favour a particular person or group of people, but rather helps those who have virtue. In Chinese we say: 皇天无 亲, 惟德是辅. 8

This innovation corresponds with the process of a religion evolving from a "natural religion” (ziran zongjiao 自然宗教) to a “moral religion” (lunli zongjiao 伦理宗 教). In contrast to the Shang, the Zhou have then to pay more attention to their moral behaviour in order to get help from the highest deity, in this case Heaven. In Chinese we say: "to prove through virtue to be worthy towards Heaven" (以德 配天). The term de 德 (virtue) plays a central role in the process of the so-called “growing ethicization of religion"9 (宗教伦理化).

Although the word de was already used in Shang times, it probably did not mean "virtue" and its use was not connected with the highest deity. In the "inscriptions on bones or tortoise shells of the Shang Dynasty" (甲骨文) for example, the word is used with the meaning “to win, to get", like the homonym de (得), or to refer to a sacrifice (Ma 2014,48). Maybe the Zhou used the original meaning of de, namely "to go straight on to the goal" (ibid.), to create a new meaning, "virtue". ${ }^{10} \mathrm{Yu}$ Jiyuan $(2009,47-50)$, who compares the word de with the Greek word "arete" and English word "virtue", states that de refers to the internal power of an individual to influence others, and primarily the ability of a ruler to control the ruled without the use of violence. ${ }^{11}$ At the same time the ruling class of the Zhou Dynasty connected this word with Heaven. As such, through de people can get the assistance of Heaven, the highest deity.

8 This probably occurs in 逸周书 (the Lost Documents of the Zhou). See 左传・僖公五年 (Zuozhuan, Xigong 5).

9 "Growing ethicization of a religion" is translation of the German Phrase "zunehmende Ethisierung einer Religion” of Ohlig $(2002,128)$.

10 According to Chen Lai de (德) was not an important term in the culture of the Shang (Chen 1996, 290). In contrast, You Huanmin (2001, 114-6) is of the opinion that de (德) was already in the Shang Era part of the category "virtue", but has given only some evidence drawn from the documents of the Shang in the Book of Documents (书经). But these cannot be seen as originally from the Shang time. The fact is that the character $d e$ 德 in "inscriptions on bones or tortoise shells of the Shang Dynasty” (甲骨文) only consists of three parts: “eye” (目), a line to above ( I ) and “to go” (行), but in "inscriptions on ancient bronze objects" of four parts: "eye", a line to above, "to go" and-be added—“heart” (心). The Chinese scholar Liu Xiang (刘翔) considers the character 徝 (zbi) in the "inscriptions on bones or tortoise shells of the Shang Dynasty" as 直 (zhi). The character 直 has a similar meaning to the character 挞 (tà) which means "go on an expedition". Therefore, Jin Chunfeng $(2007,5-6)$ is of the opinion that the word de (德 virtue) is a new construction of the Zhou.

11 Yu Jiyuan $(2009,84)$ also makes reference to discussions about the development of $d e$. 
Concerning the issue of political legitimacy, this means that the ruler has to "respect virtue" (敬德) ${ }^{12}$ in order to “keep the Mandate of Heaven” (保天命), after having received it owing to virtue of their predecessors. The best example to explain this is the chapter Zhaogao 昭诰, Duke Zhao's (昭公) imperial mandate to the young King Cheng (成王). He talks about the decline of the state of Shang, where the last king (King Zhou 纣王) mistreated the ruled people and notes: "Oh, Heaven also had pity on the people of four quarters, and removed his mandate from Yin and bestowed it on us. May the king (now) urgently respect virtue."13 For example, Duke Zhao warns the young King Cheng to learn a lesson from the decline of the Xia and Shang dynasties, and tells him: The Dynasties of Xia and Shang have lost the "Mandate of Heaven" because their last kings did not respect their virtue. ${ }^{14}$

Now we can ask: What is the content of virtue? We can just quote Michael (1986, 31) here, who writes:

What was this "virtue" on which the authority and eventually the continuation of the dynastic rule depended? It was above all concern for the welfare of the people. It had been the suffering of the people that ended the mandate for the Shang. And from the outset $\mathrm{Chou}^{15}$ rulers stressed their concern for the people's happiness.

In the opinion of You Huanmin (2001, 101, 121-4), “respect virtue" (敬德) has several meanings, but the core one is just "protect ruled people" (保民). In other words the concept of min 民 has been since the Early Zhou Era one of the most important factors in political thinking, and always in connection with the concepts of Heaven and of virtue.

12 You Huanmin $(2001,117)$ considers "respect virtue" as a development and a new slogan of the Zhou, although he-as mentioned above--believes that the Shang had already developed $d e$ as part of the category "virtue".

13 天亦哀于四方民, 其眷命用禁。王其疾敬德！ This translation comes from Karlgren $(1950,49)$.

14 The whole text: "We should not fail to mirror ourselves in the lords of Xia, we likewise should not fail to mirror ourselves in the lords of Yin. We do not presume to know and say: the lords of Xia undertook Heaven's mandate so as to have it for so-and-so many years; we do not presume to know and say: it could not be prolonged. It was that they did not reverently attend to their virtue, and so they prematurely renounced their mandate. We do not presume to know and say: the lords of Shang undertook Heaven's mandate so as to have it for so-and-so many years; we do not presume to know and say: it could not be prolonged. It was that they did not reverently attend to their virtue, and so they prematurely renounced their mandate.” (我不可不监于有夏, 亦不可不监于有殷。我不敢 知曰，有夏服天命，惟有历年; 我不敢知曰，不其延。惟不敬厥德，乃早坠厥命。我不敢 知曰, 有殷受天命, 惟有历年; 我不敢知曰, 不其延。惟不敬厥德, 乃早坠厥命。)

15 Chou is the old transcription of the Chinese character 周 (Zhou). 
As such, here I will explain the meanings of $\min$ 民: This word was already used in Shang times, but with a very different meaning than under the Zhou. This character, which we can find in several documents of "inscriptions on bones or tortoise shells of the Shang Dynasty", refers to people who are "killed to serve as a sacrifice" (mao min 印民). (Ma 2014, 280-1) ${ }^{16}$ In opposition to the Shang, the ruling class of the Zhou Dynasty obviously changed the meaning of this character (民), so that it mainly means all of the "ruled people", and is therefore a term related to the political thinking of China at this time (Du 2003, 247).

In the Da Yu Ding (大孟鼎), as discussed above, the people which the rulers of Zhou received through the "Mandate of Heaven" are regarded as shoumin (受民). Moreover, in the Zhou Book of Documents (书经) we find a more exact use, namely shouming min (受命民): ${ }^{17}$ people which are received through the "Mandate of Heaven". When the rulers of Zhou have received the "Mandate of Heaven" they have to obey Heaven in order to maintain their dynasty, and therefore have to treat the people kindly.

The fact is that for the Zhou ruling class the ruled people play an equally important role in political legitimacy as Heaven. The ruling class tried to propagate spread this idea among their peers in the defeated Shang. For example, Duke Zhou (in the chapter "Duofang" (多方)) explains this by means of describing the decline of the Xia and the assumption of power by the Shang as follows: Because the kings of Xia mistreated their people, "(Heaven) then sought a new lord for the people, and grandly it send down its illustrious and felicitous mandate to Cheng Tang, ${ }^{18}$ and it punished and destroyed the lord of Xia." ${ }^{19}$ On the other hand, the members of the Zhou ruling class also tried to convince themselves of this ideology. We think about the warning of Duke Zhao to King Cheng which we quoted above: 天亦哀于四方民. It is easy to imagine that these are all reasons why the Zhou ruling class developed the "thought of protection of the ruled people" (保 民思想).

Moreover, we can understand the change in the meaning of the word $\min$ (民) better if we analyse the "thought of protection of the ruled people". The character

16 The word mao (卯) means “to kill for sacrifice", see HYDCD 1986, Vol. 1, 311-2.

17 Duke Zhou says to King Cheng: "The King ordered me to come here. I will continue to protect the people received by Your Grandfather King Wen through the mandate of Heaven.” (周公拜手稽首 曰: “王命予来承保乃文祖受命民，...”洛诰).

18 Cheng Tang (成汤) is the first king of state Shang.

19 于惟时求民主, 乃大降显休命于成汤, 刑殄在夏。 This must be the first use of 民主 in Chinese history which means "lord of ruled people". Today the word means "democracy" after the Japanese used this term for this foreign term. 
bao (保) first meant “to take a child on the back" (背) ${ }^{20}$ (HYDCD 1986, Vol. 1, 160), therefore "to raise (a child) (养)", "to maintain" and "to protect" 21 (ibid.). This means that Zhou regarded the people they ruled after defeating the Shang as their children. The best example of this is the sentence in the above-mentioned chapter Kanggao, namely 若保赤子 (as if one protected an infant). This is a plea urge from Duke Zhou to his younger brother Kang who had received some of the Shang territory to rule.

Therefore, by changing the use and therefore the meaning of min the Zhou have not only introduced a new term into political thinking, but have also established a new kind of political rule through introducing the idea of "protection of the ruled people” (保民): the rulers as parents and the ruled as their children. Today this seems to be very conservative, but for that time it was a breakthrough in political thinking. ${ }^{22}$

The core of "protection of the ruled people" can be seen as an min (安民), which means to bring peace to the ruled people (in order to stabilize the political and social order). In the Book of Documents we often find the word kang (康), which means an (安). ${ }^{23}$ In the chapter "Kanggao", for instance, Duke Zhou urges his younger brother Kang “to protect the people by means of tranquilization" (用康 保民) and “to govern the people means of tranquilization” (用康入民). As noted above, Duke Zhou says at the beginning of this imperial mandate, "(Our) dead father King Wen was able to make bright virtue and to be careful about punishment" 24 (惟乃丕显考文王, 克明德慎罚). Here we can consider “to make bright virtue" (明德) and “to be careful about punishment" (慎罚) as two important principles to realize the "protection of ruled people" (保民)..$^{25}$

The expression “to make bright virtue" (明德) has a similar meaning as “to respect virtue” (敬德). Duke Zhou reminds his younger brother Kang of the following:

20 Besides this we can also find the word bao (保) in the chapter “Zhaogao” (昭诰):知保抱携持厥妇 子, 以哀吁天, 徂厥亡, 出执.

21 We can also find this word in “inscriptions on ancient bronze objects" (金文) like 天[...]癈保先 王 (Heaven protected our firmer kings to a great extent) in the above mentioned Da Yu Ding and 畯保四國 (to protect four states long) on the Hu Zhong from the time of King Li (庽王). (Wang Hui 2006, 65-68 and 221-4)

22 This idea has influenced political thinking in China until the present day.

23 See for example Zang Kehe (1999, 312).

24 惟乃丕显考文王, 克明德慎罚.

25 In the chapter Kanggao we also find Duke Zhou says to his younger brother: "I told you the theory of virtue and the way of punishment". (告汝德之说于罚之行) 
Grandly take as pattern the active virtue (sc. of the ancients). Thereby make steady your heart, (look at =) take care of your virtue, make far-reaching your plans and intentions, then you will make the people tranquil, and I not remove you or cut you off." 26

According to Zhou Hong $(1993,407)$, this is about the policy of "to convert the ruled people through virtue" (以德化民).

In general, Chinese culture talks about the idea "to build morality of ruled people" (教化). In the chapter "Kanggao" we can find two expressions which are used in this sense: 裕民 (yu min: to lead and educate the people) and 做新民 (zuo xinmin: to make new people). The expression yu min (裕民) occurs twice and is translated by some scholars as "to lead und educate the people." ${ }^{\text {"7 }}$ Duke Zhou asks his younger brother Kang to respect the law and follow this when leading the people. ${ }^{28}$ Duke Zhou then adds: only if you think about King Wen's respect and caution, can you lead the people. ${ }^{29}$ Secondly, Kang should treat the people of Shang kindly, who King Wen has received and must protect. He should also help the king to consolidate the Mandate of Heaven and make his subjects new people. ${ }^{30}$

To demonstrate that the three most important innovations in the thinking of the Zhou are close related to each other I would finally like to quote the last passage in the warning Duke Zhou makes to his younger brother in the chapter "Zicai" (梓材):

Great Heaven has delivered the people of the Central Kingdom and its territory to the firmer kings. Now may the king by means of virtue harmonize and gladden and (be before and after =) take care of foolish people, and thus gladden the firmer kings who received the Mandate. Yes, being an inspector like this, I say: I wish that unto a myriad years the king's sons and grandsons may forever (guard =) have charge of the people. $^{31}$

26 丕则敏德，用康乃心，顾乃德，远乃猷，裕乃以；民宁，不汝瑕殄。The translation comes from Karlgren (1950, 43).

27 Some of them thus refer to a dictionary in ancient China, namely 方言 (Dialect). According to the author of this dictionary, the word 裕 $(y u)$ is similar to 猷 (you) and has the same meaning as dao (道: “to lead”). See Jiang and Qian (1995, 282-3); You (2001, 233) and Zang (1999, 325).

28 汝亦目不克敬典, 乃由裕民.

29 惟文王之敬忌, 乃裕民.

30 乃服惟弘王应保殷民, 亦惟助王宅天命, 作新民.

31 皇天既付中国民越厥疆土于先王, 肆王惟德用, 和怿先后为迷民, 用怿先王受命。已! 若 兹监, 惟曰欲至于万年, 惟王子子孙孙永保民。The translation comes from Karlgren $(1950,48)$. 
Here I should mention that the Chinese phrase which Karlgren translates as "to have charge of the people" is bao min (保民). Therefore "to have forever charge of the people" is also one aspect or goal of the bao min (保民) policy.

\section{Conclusions}

The Zhou Dynasty is regarded as the "age of reason", and the "Mandate of Heaven” (天命), “respect virtue” (敬德) and “protect ruled people” (保民) are considered as the three most important innovations in the history of Chinese political thought at that time. Moreover, we can claim that virtue (德) stands at the centre of these innovations.

First these theories of the ruling class are based on a tripartite relationship among Heaven, the ruler and the people. Of course the ruler himself stands in the centre of this relationship, as on the one hand he has to obey Heaven as the highest deity, and on another to care for the well-being of people (敬天保民). It is obvious from texts we have from this era that the ruling class was aware of this position and role.

Certainly the Zhou-like peoples in other cultures-wish to get the favour of the gods in order to have safety and success, but they believe that they can only achieve this if they have virtue. Only through virtue can they get the favour of Heaven as the highest deity, and win the support of ruled people. Without the support of the ruled people they cannot maintain the Mandate of Heaven (legitimacy), and cannot keep their rule.

These three theories influenced the idea of political legitimacy and the political philosophy of Confucianism. I will quote some passages from Lunyu and Mengzi to show it.

The following well-known expressions of Confucius, "govern through virtue" (为 政以德, Lunyu 2.1) and "If the ruled people are led through virtue and kept in order through rites” (道之以德, 齐之以礼, Lunyu 2.3), are seen as a development of the concept “to convert ruled people through virtue" (以德化民). ${ }^{32}$

32 This thought still influences political thought in China. Although Chinese leaders have introduced the idea of 法治 (rule of law), at same time they don't want to abandon the Chinese tradition of “govern through virtue" (德政 dezheng or 德治 dezhi). Mou Zongsan talks in this case about the so-called "theory of the governance by leading of the people to virtue" (儒家的德化的治道) (Mou 2006, 24-28). Concerning the political thinking in ancient China Mou Zongsan $(2006,1)$ makes a distinction between the "right way/theory of governance" (治道) and "right way/theory of political power" (政道), which includes the assumption of political power. In this view the Confucians in ancient China did not think enough about the "right way of political power" (政道). (ibid., 13) 
This is also the case with the idea "protect ruled people". Based on this thought the Confucians developed the so-called "people-foundation-thought" (民本思 想). ${ }^{33}$ For Confucians, the state should at first help the people to "get material prosperity"(富民) and then "build their morality” (教民). ${ }^{34}$

Concerning the idea of political legitimacy two factors play key roles, namely Heaven and the ruled people. We can explain this through a passage in Mengzi, where Mencius talks about the transfer of political power from Yao to Shun (legendary emperors in Chinese history). In his opinion the ruler (in this case, Yao) may not transfer his power to someone else (i.e., Shun), before he has got the agreement of both Heaven and ruled people. ${ }^{35}$

It is interesting to note that this agreement from both Heaven and those who are ruled does not need to occur before the transfer of power, but after it. Mencius writes:

When he (Shun) was assigned the task to preside over the sacrificial offering at the ceremonial worship of the gods, all the gods came to partake of the sacrifice. This means Heaven accepted him. When he (Shun) was appointed to administer government affairs, peace and order prevailed,

33 The following phrase is seen as the first origin of the “people-foundation-thought” (民本思想): 民 惟邦本, 本固邦宁 (Only the ruled people are the root/foundation of a state; if the foundation solid, there is peace in the state.). This phrase occurs in the chapter "Wuzi Zhige" (五子之歌) which concerns the time of the Xia, but this document is not seen as originally from that era. This idea (民本思想) also influences contemporary China.

34 "The Master (Confucius) went to the state of Wei and Ran You (a pupil of Confucius) acted as driver of his carriage. The master observed: 'How numerous are the people!' Ran You asked: 'Since they are thus numerous, what more shall be done for them?' The Master answered: 'Enrich them!' And when they have been enriched, what more shall be done for them?' The Master said: 'Teach them!” (子适卫, 再有仆。子曰: “庶矣哉! ”舟有曰: “既庶矣, 又何加焉？”曰: “富之。” 曰: “既富矣，又何加焉？”曰: “教之。”(Lunyu 13.9)

35 "Wan Zhang (a pupil of Mencius) asked: 'Was it the case, that Yao gave (power over) the world to Shun?' Mencius replied: 'No, the son of Heaven (sovereign) cannot give (power over) the world to another.' Wan Zhang: 'Yes. But Shun has got (power over) the world. Who gave it to him?' Mencius: 'Heaven did.' Wan Zhang: 'How did Heaven give it to him? Was it by detailed instructions?' Mencius: 'No, Heaven does not speak, but shows its intension through acts and events.'Wan Zhang: 'How is it done?' Mencius: 'The Son of Heaven can recommend a man to Heaven, but he cannot make Heaven give (power over) the world to the man recommended. (...) In ancient times Yao recommended Shun to Heaven and Heaven accepted him, Yao presented Shun to the people and the people accepted him. That is what I mean by saying: Heaven does not speak, but shows its intention through acts and events'.”(万章曰: “尧以天下与舜，有诸？”孟子曰: “否。天 子不能以天下与人。”然则舜有天下也, 勍与之? ” 曰: “天与之。” 曰: “天与之者, 谆谆 然命之乎? ”曰: “否。天不言, 以行与事示之而已矣。”曰: “以行与事示之者, 如之何?” 曰: “天子能荐人於天, 不能使天与之天下。[...]昔者, 尧荐舜於天而天受之, 暴之於民而 民受之。故曰: 天不言, 以行与事示之而已矣。”Mengzi 9.5) 
and people were happy and content. This means the people accepted $\operatorname{him}^{36}$

It is also interesting to note that for Mencius the people seem to be more important than Heaven. First, he quotes the following passage from the Book of Documents (书经): “People's eyes are the eyes of Heaven; people's ears are the ears of Heaven." ${ }^{37}$ Second, he explains why the last kings of Xia and Shang lost their power as follows: "Jie (the last king of Xia) and Zhou (the last king of Shang) lost (power over) the world, because they lost (support of) the people." He continues: "There is a right way to get (power over) the world: win the people's support and you will get (power over) the world. There is a right way to win the people's support: win their hearts and you will win their support." 38

\section{References}

Chen, Lai 陈来. 1996. Gudai zongjiao yu lunli - Rujia sixiang de genyuan 古代宗 教与伦理——儒家思想的根源 (The Religion and Ethics of Ancient ChinaThe Origin of the Confucian Thinking). Beijing: Sanlian Shudian.

Debson, W. A. C. H. 1962. Early Archaic Chinese. A Descriptive Grammar. Toronto: University of Toronto Press.

Du, Lun 杜仑. 2003. “Bedeutung des Begriffs min (Volk) in der frühen ZhouZeit. Eine sprachliche Analyse der Zhou-Dokumente im Shujing (The Use of the Term min (people) in the Early Zhou Period. A Study of the Zhou Documents in the Shujing)." In Brücke zwischen Kulturen. Festschrift für Chiao Wei zum 75. Geburtstag (Bridge between Cultures), edited by Karl-Heinz Pohl and Dorothea Wippermann, 229-52. Münster u.a.: Lit Verlag.

HYDCD. 1986. Hanyu da cidian 汉语大字典 (The Great Lexicon of the Chinese Characters). Chengdu: Sichuan Cishu Chubanshe.

36 使之主祭, 而百神享之, 是天受之; 使之主事而事治, 百姓安之, 是民受之也。 (Mengzi 9.5)

37 “《太誓》曰: ‘视自我民视, 天听自我民听。’此之谓也。”(Mengzi 9.5)

38 得天下有道: 得其民, 斯得天下矣。得其民有道: 得其心, 斯得民矣。 The whole text: “Jie (the last king of the Xia) and Zhou (the last king of the Shang) lost (power over) the world, because they lost (support of) the people. They lost (support of) the people, because they lost their hearts. There is a right way to get (power over) the world: win the people's support and you will get (power over) the world. There is a right way to win the people's support: win their hearts and you will win their support. There is a right way to win their hearts: collect for them what they desire and do not force on them what they hate.” (桀纣之失天下也，失其民也。失其民者，失其心也。得天下 有道: 得其民, 斯得天下矣。得其民有道: 得其心, 斯得民矣。得其心有道: 所欲与之聚 之, 所恶勿施尔也。Mengzi 7.9) 
Jiang, Hao 江影, and Zongwu Qian 钱宗武. 1995. Jin Gu wen Shangshu quanyi 今古文尚书全译 (The Translation of the Whole Jinwen-and Guwen Texts of the Shujing). Guiyang: Guizhou Renmin Chubanshe.

Jiang, Shanguo 蒋善国. 1988. Shangshu Zongshu 尚书综述 (A Comprehensive Explanation of the Shujing). Shanghai: Shanghai Guji Chubanshe.

Jin, Chunfeng 金春峰. 2007. “De' de lishi kaocha “德”的历史考察 (A Historical Survey of the Word de).” Shaaxi Shifa Daxue Xuebao 陕西师范大学学报 6: 5-12.

Karlgren, Bernhard. 1950. "Book of Documents." Bulletin of the Museum of Far Eastern Antiquities Stockholm 22: 1-81.

Liang Tao 梁涛, and Baocai Liu 刘宝才著. 2005. Zhongguo xueshu sixiang biannian, xian Qin juan 中国学术思想编年, 先秦卷 (The Chronicle of the Academic History of China), edited by Zhang, Qizhi 张岂之. Xi'an: Shaanxi Shifan Daxue Chubanshe.

Ma, Rusen 马如森. 2014. Yin xu Jiaguwen shiyong zidian 殷墟甲骨文实用字典, Xin ban新版, (A Practical Dictionary of the Inscriptions on Bones or Tortoise Shells from the Ruine of the Yin Period), New Edition. Shanghai: Shanghai Daxue Chubanshe.

Ma, Tianxiang 马天翔, and Jiazhi Xiao 萧嘉祉. 1991. Gu Hanyu tongjiazi zidian 古汉语通假字字典 (Lexicon for Homophone Characters in the Classical Chinese).Xi'an: Shaanxi Renmin Chubanshe.

Michael, Franz. 1986. China through the Ages. History of a Civilization. Boulder and London: Westview Press.

Mou, Zongsan 牟宗三. 2006. Zhengdao yu zhidao 政道与治道 (The Way of Politics and the Way of Governance). Guilin: Guangxi Shifan Daxue Chubanshe.

Ohlig, Karl-Heinz. 2002. Religion in der Geschichte der Menschheit: Die Entwicklung des religiösen Bewusstseins. Darmstadt: WBG.

Wang, Hui 王辉. 2006. Shang Zhou jinwen 商周金文 (The Inscriptions on Ancient Bronze Objects of the Shang and Zhou periods). Beijing: Wenwu Chubanshe.

You, Huanmin 游唤民. 2001. Shangshu soxiang yanjiu 尚书思想研究 (Study of the Thinking in the Shujing). Changsha: Hunan Jiaoyu Chubanshe.

Yu, Jiyuan 余纪元. 2009. Dexing zhi jing: Kongzi zu Yalishiduode de lunlixue 德性 之镜: 孔子与亚里士多德的伦理学 (Mirror of Virtue: The Ethics of Confucius and Aristotle). Beijing: Zhongguo Renmin Daxue Chubanshe.

Zang, Kehe 藏克和. 1999. Shangshu wenzi jiaogu 尚书文字校诂 (Correction and Explanation of the Texts and Characters in the Shujing). Shanghai: Shanghai Jiaoyu Chubanshe.

Zhou, Hong 周洪. 1993. “Shangshu zhijie 尚书直解 (The Translation of the Book of the Documents)." In Shisanjing zhijie 十三经直解 (Di yi juan 第 一卷), edited by Anqun Zhu et al. 朱安群 等, 303-491. Nanchang: Jiangxi Renmin Chubanshe. 